\title{
Accounting for Crimes: The Role of International Criminal Tribunals in Effectively Addressing Impunity
}

\author{
Iris Almeida
}

\begin{abstract}
In this paper, the author examines the ways in which accountability for international crimes could become a practical reality. She takes the position that "impunity" is inimical both to justice, and to lasting peace and democracy in post-conflict societies and proposes a conceptual framework for the international rule of lawas an alternative. She also argues that a strong, independent and permanent International Criminal Court (ICC) would ensure the kind of universal enforcement of international law that will lead to a progressive, long-term reduction of human rights violations.
\end{abstract}

\section{Précis}

Dans cet article, l'auteur examine de quelle façon la responsabilité juridique pourcrimes internationaux peut devenir une réalité pratique. Elle défend la position selon laquelle l'idée d' «impunitée» est incompatible autant avec l'idée de justice, qu'avec les idées de paix durable et de démocratie dans les sociétés postconflictuelles. Elle propose comme alternative un cadrage conceptuel pour le code des lois internationales. Elle développe aussi l'argumentation selon laquelle la Cour pénale internationale (CPI) serait le plus sûr garant du seul type d'application des lois internationales susceptible de mener d long terme d une graduelle réduction des violations des droits humains.

Genocide, ethnic cleansing, crimes againsthumanity. These are words that conjure up powerful images of extreme brutality and utter disregard for the dig -

Iris Almeida is the Director of Programs at the International Centre for Human Rights and Democratic Development (ICHRDD), Montreal, an independent and non-partisan organization established in 1988 by an act of the Parliament of Canada. nity of the human being, and are often associated with the Second World War. But crimes of this heinous nature continue to occur around the world, even as we speak. In early May of this year, British Rights Activists witnessed "widespread systematic destruction" in southern Sudan, as government-armed Islamic fundamentalists slaughtered hundreds of mostly Christian civilians. ${ }^{1}$ In Sierra Leone, withdrawing military forces have reportedly destroyed at least 36 villages in recent weeks, while committing horrific atrocities against unarmed civilians, including rapes, mutilations and killings. ${ }^{2}$ And in Afghanistan, the Taliban army has recently blocked supply routes to the Hazarajat region, home to an ethnic minority of more than 1.5 million, in order to starve the "rebels" who presently control the region; but instead, it is civilians who are starving and dying. ${ }^{3}$

In all of these cases, little or nothing has been done. Perpetrators of these crimes are in effect able to continue to violate international law with impunity, as the international community looks on with indifference, or simply paralysed by political considerations. Clearly, the situation must change.

And there are modest signs that it will. Indeed, the search for stable, credible, non-politicized mechanisms for dealing with heinous international crimes might be approaching an historic moment. Between June 15 and July 17 of this year, delegations representing 148 member states of the United Nations convened in Rome in order to negotiate a treaty establishing a permanent International Criminal Court (ICC). On July 17,1998 the statute was adopted after a dramatic vote requested by the United States in which 120 states voted in favour, 21 states abstained and 7 states voted against. For the statute to come into force and the Court to be established, 60 states must now ratify the treaty. If established in the right way, this Court could strike a formidable blow against violators of international law, who, in so many cases, have managed to flout international legal norms for far too long, managing to avoid any form of accountability for their crimes.

Why should Canadians care if these violations only occur in countries separated from us by distance and culture? In short, because human rights violations hurt all of us. Ensuring the strict and uniform application of international law to the perpetrators of such crimes is of vital importance for all Canadians for a number of reasons.

Firstly, on a purely philosophical and cultural level, the protection of human rights are rooted in universal values that Canadians share: heinous crimes, such as genocide, mass murders, torture, rape and military sexual slavery have long been and continue to be repugnant acts that are simply unacceptable to Canadians. The values that Canadians share with citizens around the globe require that efforts be made to stop such crimes when possible, and to do all that can be done to bring the perpetrators of such crimes to justice.

Secondly, in 1997-98, it is estimated that $\$ 90$ million of the Canadian International Development Agency (CIDA) was oriented to human rights, democratic development and good governance initiatives in overseas developmental assistance countries. Yet impunity, as we shall see, in so far as it acts as a stumbling block for democracy, stands to wholly frustrate these Canadian foreign policy objectives in developing countries. Human lives, including those of Canadians working for change in these regions, truly do hang in the balance.

Finally, Canadian foreign policy has made a priority of providing international leadership in the battle against impunity by pursuing several avenues 
in the field of international law and justice. Our government has demonstrated a firm commitment to treaties on international crimes by not only adopting and ratifying them itself, but also by encouraging other states to dolikewise. Moreover, Canada has pledged its support for the creation and effective implementation of international ad hoc tribunals for the former Yugoslavia and for Rwanda, with particular emphasis on programmes of witness protection. Most recently, Canada has been at the forefront of the group of like-minded states advocating for the creation of a strong International Criminal Court at the Conference of Plenipotentiaries. Given this agenda, it is imperative that Canadians be aware of the key issues, in order toevaluate and keep a close eye on their government's policy direction with respect to initiatives against impunity in general and the International Criminal Court in particular.

It is with these considerations in mind that we propose to examine the ways in which accountability for international crimes can become a practical reality. In order to do so, however, we must first establish, in specific terms, the reasons why impunity is inimical not only to justice, but also to lasting peace and democracy in post-conflict societies, and therefore why the battle against impunity is so critical. We will then attempt to evaluate the relative success of the various mechanisms which have aimed, since World War II, to apply international law to perpetrators of heinous crimes both in international and domestic armed conflict situations. Finally, as we shall see, for true justice to be served, it is essential that international law and international legal tribunals take account of gender-sensitivity: the perspective of the female victim and witness of sex or gender-related crimes must be reinforced. .

\section{Combatting Impunity: The Importance of Bringing Perpetrators of International Crime to Justice}

Before addressing the ways in which impunity for international crimes has been and could be combatted, itisessential to first understand why the battle against impunity is socrucial. To do so, let us begin by defining a concept inextricably linked to impunity: the international rule of law. This will allow us to highlight the connection between impunity for violentcrimes and the vicious circle of continuing violence which plagues a considerablenumber of countries where the rule of law is, for all intents and purposes, nonexistent.

\section{The Culture of Impunity: Flouting the Rule of Law}

The notion of the "rule of law" is one of the most basic principles of internal law, i.e., the law that applies within the territory of a sovereign state. Although thespecificmeaning given to the expression "rule of law" might differ from society to society, at least one fundamental element reoccurs in almost all domestic legal systems: the "justiciability of fundamental rights," that is the ability for citizens to "invoke guaranteed rights and freedoms before tribunals against all organs of the State." ${ }^{4}$ This, in turn, provides the basis for equality within a democratic regime, because no citizen, not even a government leader, is above the rule of law.

In the international system, the concept of a rule of law is rather novel, yet, without question, it has begun to take root as a desirable, if not essential objective. Indeed, it was the almost unfathomable brutality and scope of the atrocities committed during the two World Wars that shocked the conscience of humankind and moved the international community into action towards establishing an international rule of law. Since then, numerous international treaties and conventions were adopted in order to protect themost fundamental rights of human beings and to ensure that such atrocities would never happen again.

As a result, international law, a mixture of customary and treaty-based law, as it stands today, does in fact criminalize certain egregious violations of human rights from which, in theory at least, no domestic law can derogate. These crimes, which include crimes againsthumanity, genocide and war crimes, ${ }^{5}$ are characterized as having attained a level of jus cogens: they establish "inderogable protections and the mandatory duty to prosecute or extradite accused perpetrators, and to punish those found guilty, irrespective of locus since universal jurisdiction presumably applies." 6

The problem is, international law on jus cogens crimes is simply not being applied uniformly and systematically, as the principles of the rule of law and of justice dictate. This means that a considerablenumber of perpetrators of international crimes have been successful in flouting the international rule of law and escaping punishment. ${ }^{7}$ This culture of impunity has serious consequence for the stability and well-being of post-conflict societies.

\section{Impunity Begets Further Crime:}

The Vicious Circle of Violence

When perpetrators of horrific crimes such as genocide, war crimes and crimes against humanity go unpunished, the consequence is not simply an offence to morality, but in fact represents one of the most dangerous obstacles to peace and democracy: an unending cycle of revenge and retributory violence.

Indeed when victims of international crime are given no recognition and no means for peaceful, legal redress, they become cynical and frustrated with the state. Theybegin toturn to violentmeans in order to seek revenge, in order to seek a kind of personal or vigilante justice. ${ }^{8}$ This further undermines transitional regimes, which are already fragile, and can sometimes lead to their total destruction.

Several worrying events around the globe provide compelling illustrations of this phenomenon. Earlier this year, we witnessed the hostage-taking and ensuing stand off with government officials in Peru by the Tupac Amaru guerilla forces. More recently, one can point to the attack on security personnel at a Colombian prison by the Revolutionary Armed Forces of Colombia, which allowed more than 324 inmates to flee. ${ }^{9}$ Such violent outbreaks arenot confined to Latin America: ethnic minority rebels 
in the break-away Abkhazian region of the Republic of Georgia have now been accused of ethnic cleansing againstethnic Georgians living in and around this region. ${ }^{10}$

All of these cases are telling examples of how impunity can set-off an unending spiral of violence for past suffering. The instability generated by such vigilante justice only serves to undermine democracy, by lending credence to the claims of military leaders that only tyrannical governance can ensure peace. This, in turn, spurns more violence against so-called dissidents, and both peace and democracy collapse. This is precisely what occurred in Argentina in the 1960s and 1970s. As recent events indicate, if effective measures are not taken to end impunity, the same pattern of violence to avenge violence can once again set in, as is the case in Latin America, where fledging, transitional democratic regimes are struggling to stay afloat.

\section{Criminal Prosecutions: Breaking the Chain of Violence}

One of the keys to stopping the chain of violence is to end impunity for the crimes of tyrannical government leaders of the past before the cynicism and frustration of citizens pushes them to see vigilante justice as the only acceptable solution. If transitional regimes are to garner the kind of widespread, popularsupport they need to be durable, then they must dare to use in a timely manner the windows of opportunity available to them in the early phase of transition, before the euphoria fades. They must ensure that appropriate legal mechanisms are established and adequately funded with international, bilateral and multilateral cooperation, so as to seekoutand hold accountable perpetrators of past human rights violations. The objectives of these mechanisms should be three-fold:

1) investigate and make public the

"Truth": for a victim of a crime againsthumanity, the "right to truth is a part ... of a greater right to justice;" thus the State has an obligation to "establish the truth about the repressivestructure that led to thecom- mission of [such crimes], including the chain of command, the orders given, the establishments that were used, and the mechanisms knowingly used to insure impunity and secrecy in these operations;" 11

2) allow for adequate redress for victims: this should include, where appropriate, financial compensation, rehabilitation (physical, psychological, etc.) and restitution (if possible,e.g., returning wrongfully seized property, restoring a job to victim who was imprisoned, etc.). ${ }^{12}$

3) ensure a fair and impartial trial, based on the principle of the rule of law: not only must justice be done, it must be seen to be done. This means that prosecutions should be widely publicized and accessible and that they must not be based on ex post facto laws, but rather on well established international law, such as the jus cogens law against genocide, war crimes and crimes against humanity. Procedures must also be strict: due process and the accused's right to full answer and defence must be upheld. ${ }^{13}$

Access to the Truth, adequate redress and bona fide prosecutions are all fundamental obligations placed on States by international law. ${ }^{14}$ They are also a very necessary step in ensuring that a society emerging from government-sponsored mass victimization can heal itself and move forward.

\section{Mechanisms of Accountability: An Historical Review of Post-World War II Initiatives}

If ending impunity is such a critical goal to ensure peace and democratic development through the application of the rule of law, how have domestic and international law fared in achieving this goal?

Unfortunately, one quickly realizes that the results are inconsistent at best and sorely inadequate at worst, despite some successes in fighting impunity in certain particular cases. Let us examine the various accountability mechanisms established and in use since World War II, by focusing firstly on the domestic level and, secondly, on the international level. Is there any alternative to these institutions for dealing with the kinds of pervasive massive human rights violations and for battling impunity for these crimes, both of which continue to this day?

\section{The Role of Domestic Law}

In an ideal world, every state would not only have internal laws that prohibit the kinds of egregious violations of human rights that genocide, war crimes and crimes against humanity represent, but they would also have the kinds of judicial instruments that would allow for the effective prosecution and punishment of such crimes. Sadly, in so many countries, this is simply not the case.

Instead, even when laws do exist, their enforcement is rendered impossible because of either a lack of resources, a lack of political will, or both. Witness the 1997 show trial of Pol Pot carried out by his Khmer Rouge comrades in Cambodia: although sentenced tolifeimprisonment, Pol Pot died in April of this year, without ever having served even one day of his sentence. He lived with outright impunity until the very end, surrounded and protected by his supporters, who still revered him. Pol Pot died without ever being held accountable for the genocidal massacre of 2 million Cambodians, which he is alleged to have personally engineered. Clearly, in the case of Cambodia, domestic courts were simply unwilling and unable to serve justice.

Of course, it is political interests that create this institutional incapacity and inaction. Such has also been the case not only in Cambodia, butalso in Colombia, Venezuela and Brazil in recent decades. Furthermore, often times, due to political pressures, or simply as a prerequisite for the cessation of hostilities, would-be or recently installed civil governments are compelled to offer military criminals blanket amnesty for all serious crimes. Laws establishing such blanket amnesties were especially frequent in Latin America during the 1980s and 1990s, as evidenced by the cases of ElSalvador, Guatemala, Haiti, Peru and Uruguay. 15 
The case of South Africa may represent a counter-example, however. Some argue that the choice to emphasize national reconciliation by offering selective amnesty through a Truth and Reconciliation Commission (TRC) was a necessary compromise between " $\mathrm{Nu}$ remberg-style trials for the leaders of the former apartheid government" and "blanket amnesty," both of which would have led to the break-down of negotiations between the African $\mathrm{Na}$ tional Congress [ANC] and the de Klerk government that ultimately resulted in the end of the apartheid regime. ${ }^{16}$

Furthermore, the TRClegislation did not allow for the kind of impunity seen in Latin America. Under the TRC law, amnesty was only granted after a suspect applied to the TRC, and through his or her testimony, provided the Commission with what was judged to be "full disclosure" of his or her human rights violations, based on specific criteria laid out in the legislation. Furthermore, the law prescribed time limits for applications: 14 May 1997 was the cutoff point. From that point onwards, no amnesty could be granted by the Commission. 17

Nevertheless, it remains to be seen whether the South African Truth and Reconciliation Commission can "serve justice in a longer term perspective." ${ }^{18}$ In other words, although it is undeniable that the political compromise reached in South Africa with respect to accountability for crimes under the former tyrannical regime allowed for the transition to a democratic regime, the fact remains that domestic law makes this regime, in many cases, unable to punish perpetrators of crimes that are clearly illegal under international law.

Indeed, the question becomes even more pertinent when one considers the blanket amnesty laws of Latin America, not to mention the judicial vacuum witnessed in Cambodia. Do any mechanisms exist at the international level to ensure that, regardless of domestic legal and political particularities and inadequacies, perpetrators of heinous crimes are still made to answer for them?

\section{International Law in a Domestic Context}

When domesticlaw proves inadequate, what role can be played by international law? In principle, as we have already seen, international law, as it has developed through custom, judicial precedent and treaty, currently proscribes a number of jus cogens crimes, including genocide, war crimes, and crimes against humanity. ${ }^{19}$ The high status of this law has at least two significant consequences. Firstly, there is an obligation (obligatio erga omnes) placed upon states to extradite or prosecute an accused suspected of having committed one or several of these crimes (also known as the principle of "aut dedere aut judicare") whenever there is sufficient evidence to support these allegations. Secondly, these crimes are punishable by any state, regardless of the exact geographic location in which they were committed. In other words, according to this principle, commonly referred as to universal jurisdiction, international law recognizes any state has the requisite sovereignty to prosecute $j u s$ cogens crimes, even when they are committed outside the territory of that particular state. $^{20}$

The problem is that in practice, these principles of international law are often not implemented by states, in spite of their signatures and ratification of numerous international treaties. There are of course exceptions. For example, Canada and Belgium, in addition to having ratified the Geneva Conventions, have adopted internal laws that specifically proscribe the most serious international crimes, such as genocide and war crimes. 21

Other exceptions to this rule of nonimplementation can be seen in certain countries of the South that have carried out domestic prosecutions of persons accused of gross violations of human rights. For one, Ethiopia has been investigating and prosecuting, since 1993, individuals responsible for genocide and war crimes that occurred under the Mengitsu military dictatorship, which plagued that country from 1974 to 1991.22 And Argentina has prosecuted in the past decade or so, numerous military leaders who had carried out forced disappearances during the "Dirty War" of the 1970 s and early $1980 \mathrm{~s}^{23}$

But even in cases such as these, where domestic law specifically allows for the criminal prosecution of those accused of international crimes, legal institutions may often not have the kinds of resources necessary for carrying out adequate investigations and prosecutions. Further, political leaders may interfere with the judicial process, in order to spare military leaders who are allies of theirs in government. Or worse yet, the entire judicial system itself might be so unstable or corrupt as to make the goal of fair and expeditious trials completely unattainable. ${ }^{24}$

How can we ensure, in the light of theseshortcomings of domestic regimes in the implementation of international criminal law, that impunity for the most serious crimes does not continue unopposed in the future?

\section{The Lessons of Nuremberg, The \\ Hague and Arusha: The Relative Progress of Ad Hoc International Criminal Tribunals}

The international community has, on a small number of occasions, found the courage and political will to come together in order to fight impunity by overcoming the paralysis or non-existence of strong, impartial domestic legal institutions. The solution adopted in these cases was an international criminal tribunal.

The Nuremberg Trials immediately proceeding the Second World Warwere an important step in the process towards a stable and meaningful international rule of law. At the time of the formal adoption of the International Military Tribunal Charter in 1945, Germany was being occupied by Allied troops and German sovereignty was effectively being exercised by Allied powers. Assuch, in order toensure a fair and efficient trial of senior Nazis, it was obvious that an international effort would be required.

Pursuant to the IMT Charter, which was eventually signed by nineteen 
states, ${ }^{25}$ the Tribunal was to have jurisdiction over three crimes: the "crime against peace," "crime against humanity" and "war crimes." 26 The United States especially saw these trials as a unique opportunity to make binding international law and was therefore adamant that they be carried with impartiality and be limited to the specific crimes appearing in the Charter. Efforts were made by British and American prosecutors to emphasize at the time that the justice being meted out at $\mathrm{Nu}$ remberg was not retroactive: the crimes specifically punishable under the IMT Charter were simply derived from prior customary international law. ${ }^{27}$

It took almost fifty years, but the precedent of Nuremberg was finally made use of during the decade of the 1990s, which saw the creation of two more ad hoc international criminal courts: the International Criminal Tribunal on the Former Yugoslavia (ICTY) at the Hague and the International Criminal Tribunal on Rwanda (ICTR) at Arusha. Both of these ad hoc tribunals were set up following large-scale human atrocities which galvanized the international community towards, among other measures, a judicial response to the crimes thathad already been committed in order to fight impunity and create some kind of deterrent effect against further massive violations of international law.

In effect, the ICTY and ICTR were a considerable improvement upon the Nuremberg precedent, which some have called "victors' justice." Not only did the ICTY and ICTR incorporatenew substantive international law from the past fifty years to the precedents of Nuremberg, particularly with respect to the procedural rights of the accused, these ad hoc tribunals are truly international bodies in the sense that both their judges and their prosecutors are supplied by a wide variety of countries, none of which were parties to the conflict which gave rise to the crimes being prosecuted. ${ }^{28}$

Nevertheless, while these tribunals have represented significant progress towards a strong and stable international rule of law and the elimination of impunity for serious human rights violations, they have not escaped criticism and controversy. The main deficiency plaguing these types of ad hoc tribunals is their vulnerability to political manipulation and obstructionism.

In the first place, achieving consensus on how and when they are created and how they will function is no easy task: it took the Security Council almost two years between the time at which it was first informed of the atrocities being committed in Yugoslavia and the date at which it finally appointed a Prosecutor; two years later, although seventy-five indictments had been issued, only two individuals had stood trial. ${ }^{29}$ Furthermore, the ability of such tribunals to effectively apprehend and prosecute suspected international criminals is severely hampered by the noncooperation of states, such as the Federal Republic of Yugoslavia (Serbia and Montenegro), that harbour these suspected criminals, because these individuals are intimately linked to the political leadership of the state, if they arenot the actual political leaders themselves. ${ }^{30}$ Finally, precisely due to the non-permanent nature of these tribunals, any deterrent effect is almost certainly lost, not only for would-be criminals in states other than the former Yugoslavia and Rwanda, since the ICTY and ICTR only have jurisdiction over those territories, respectively, but also because, even within those regions, the tribunals are temporally constrained and generally lack adequate resources, such that there is no guarantee of how long they will continue to exist.

\section{Towards an Effective International Criminal Court: Making the Right Choices}

These deficiencies highlight the grave importance of a permanent and effective International Criminal Court (ICC) in the quest for $a$ uniform and systematic application of international law to end the culture of impunity that prevails in so many countries around the world. Indeed, only a strong, independent and permanent ICC can ensure the kind of universal enforcement of international law that will lead to a progressive, longterm reduction of human rights violations.

Building on the work of the International Law Commission during the late 1940s until the mid-1950s, which led to a Draft Statute for an ICC in 1954 that was never formally adopted by any state, the UN once again began in 1989 to develop a statute that would provide for the establishment of a permanent ICC. Since 1989, a total of six UN Preparatory Committees have progressively refined the Draft Statute of the ILC. It would have appeared that all that was left to be done was to adopt it. The truth is, at the commencement of the United Nations Diplomatic Conference last June, the Draft Statute still contained over 1,300 bracketed texts and offered numerous options to choose from.

Thus, there remained a significant chance that states will be pressured towards a sort of lowest common denominator consensus, which would be truly anathema to the underlying goal of battling impunity. In the opinion of numerous leading non-governmental organizations and human rights defenders, a weak, toothless court could be even worse than no court at all, because it would only encourage further atrocities by proving the international community's lack of resolve when it comes to the battle against impunity.

In order to ensure that the ICC would be truly credible and effective, unprecedented concerted lobbying action was pursued by non-governmental organizations and a group of like-minded states went on. Their work focussed on ensuring some of the following essential attributes:

1) guaranteed inherent jurisdiction over genocide, crimes against humanity and war crimes: as in the case of the ICTY and ICTR, the Courtmust be empowered to be seized with cases involving these most serious international crimes, regardless of the citizenship or physical location of the accused. States must notbeentitled to opt-out of the Court's jurisdiction at their will if an effective and uniform ap- 
plication of international law is desired.

2) an independent Prosecutor: the Prosecutor must have an ex officio power to launch investigations based upon information from a wide variety of sources, and not exclusively on the basis of a situation referred by the Security Council or a given State. An independent Prosecutor would not only ensure that political concerns do not taint the judicial process through obstructionism, but would also contribute to a more vigourous battle against impunity.

3) statecooperation: in order to avoid the kinds of obstacles which have afflicted the ad hoc tribunals of the recent past, the ICC needed the power to compel states to apprehend and transfer suspects, to grant access to witnesses and to gather and share evidence. The Court judgements needed the power to be enforced by signatory states, including the sentences and compensation orders for victims.

4) recognition of the specificity of genderrelated crimes and capacity to protect victims and witnesses of such crimes: the ICC statute needed to expressly include gender-specific crimes as coming under crimes against humanity. Rape and other similar crimes of serious sexual violence and abuse aimed specifically at women have for too long been ignored. As well, mechanisms needed to be set up to provide adequate witness protection and preparation for trial, so as to avoid the revictimization of vulnerable witnesses, particularly women victims of sexual violence, who might suffer reprisals in their communities for coming forward. Indeed, if the Court did not wish to deter victims from coming forward in the first place, their anonymity was tobe guaranteed. Finally, Court personnelneeded to include experts in gender issues, so that all stages of the trial, from investigation to indictment, prosecution and/or sentencing were to be free of gender-based discrimination.
The key highlights of the Statute adopted in Rome may be succinctly summarized as follows:

The Court will prosecute natural persons (individuals) (article 25). It will cover events that occur once the treaty is in force (article 11). The Court will have "automaticjurisdiction" over genocide, war crimes, crimes against humanity and aggression (article 5). The crime of aggression will be defined at a later date. The Court will be divided into 4 organs: the Presidency, the Divisions of the Court, the Office of the Prosecutor and the Registry (article 34). 18 Judges will sit on the Court and serve on a full-time basis for a 9 year term of office (articles 35-36). States would have to take into account the need for fair gender and regional representation in the choice of judges (article 36 paragraph 8). Cases can be referred to the Courtby Prosecutor, the UNSecurity Council or by statesparties (article 13). The Prosecutor thus will have the ability to start investigations proprio motu. The Court may exercise jurisdiction only when one of two states is a state party or gives its consent, namely the state of the nationality of the accused or the territorial state (article 12). Noninternational armed conflict which is the predominant form of conflict in the world today is included in the definition of war-crimes (article 8). Crimes againsthumanity will have to be "widespread and systematic" as well as linked to a policy and directed at civilians (article 7). This will effectively prevent the Court from taking up isolated acts, regardless of how horrific these acts and their consequences are. Gender crimes such as forced prostitution, trafficking in women and children and forced pregnancy are included as war crimes and crimes against humanity (article 7 paragraph 2(f); article 8 paragraph 2(b)(xxii)). The Statute provides for a victim and witness unit under the Registrar (article 43 paragraph 6), as well as a Legal Advisor on Gender crimes (article 42 paragraph 9). The death penalty which is still part of domestic law in many countries was not included. Although the Court does not have the power to order state compliance itself, the Court may request the states parties to cooperate (articles 8687 ). This cooperation includes collection of evidence, arrest and surrender of a person, protection of victims and witnesses and seizing proceeds of crimes (articles 89-93). No reservations are permitted under theStatute (article 120).

Clearly the Statute adopted remains far from perfect. Nevertheless, it is the best possible compromise that could be negotiated in order to get the largest number of states to adopt it and thus enhance the potential for its ratification and coming into force.

\section{Conclusion}

The opportunity to finally establish a strong, stable and uniform application of international law through the creation of a permanent International Criminal Courtnow stands before us. The key is to learn from the past, and in particular, from the moderate successes and undeniable shortcomings of the various legal mechanisms used over the past five decades to combat impunity.

Only an international rule of law that provides access to truth and equal justice for all can effectively end the cycle of violence and instability that has plagued so many countries attempting to undergo the often turbulent and painful transition from tyranny to democracy. As we have seen, it is only by holding perpetrators of gross human rights violations accountable for their crimes that we can move forward. Justice truly is the sine qua non condition for long-lasting peace and democratic development.

In order to ensure that this historic opportunity is not lost, members of civil society must mobilize state action. States must be reminded of the importance of actually following through with their commitments in the battle for the universal application of humanitarian law and respect for human rights in general. To further this end, civil society must demand not only continued state support for existing accountability mechanisms, whether theybe domestic courts or international ad hoc tribunals, butalso must lobby for the early ratification of the ICC treaty by at least 60 states so that an effective and credible Interna- 
tional Criminal Court can come into force. The battle for Truth and Justice for all citizens of the world is far from being won. Nevertheless, if the necessary political will can be mustered in the coming months and years, we will certainly succeed in striking a formidable blow against impunity and thus provide the necessary environment for participatory and sustainable democratic development.

\section{Notes}

1. C. Davies, "Genocide in Sudan: Aidworker Reports on Aftermath," The [Montreall Gazette, May 26, 1998, at B1.

2. J. Beltrame, "World's Fury Rains Down on Pakistan," The [Montreal] Gazette, May 29, 1998, at B1.

3. Ibid.

4. J.-Y. Morin, "L'État de droit: émergence d'un principe de droit international" (1995). Recueil de cours de l'Académie de droit international 10 at 182 [author's translation].

5. Some jurists would also include torture, aggression, piracy, slavery and slave-related practices as crimes of jus cogens. See, for example, C. Bassiouni, "International Crimes: Jus Cogens and Obligatio Erga Omnes" [hereinafter C. Bassiouni, International Crimes], in C. Bassiouni \& C. Joyner, eds., Reining in Immunity for International Crimes and Serious Violations of Fundamental Human Rights: Proceedings of the Siracusa Conference 17-21 September 1997, (Quercy: Association internationale de droit pénal, 1998) 133 at 139.

6. C. Bassiouni, "Searching for Peace and Achieving Justice: The Need for Accountability" [hereinafter C. Bassiouni, Accountability] in Joyner \& Bassiouni, eds., supra note 5,45 at 56 .

7. For example, among the estimated 285 armed conflicts between 1945-1996, only 49 had given rise to some form of legal redress: see J. Balint, “An Empirical Study of Conflict, Conflict Victimization and Legal Redress 1945-1996," in Joyner \& Bassiouni, eds., supra note 5, 101 at 119.

8. See, for example, N. Kritz, "Coming to Terms with Atrocities: A Review of Accountability Mechanisms For Mass Violations of Human Rights," (1996) 59:4 Law and Contemporary Problems 127 at 128.

9. Serge F.Kovaleski, "Rebels GiveColombia a New Black Eye," International Herald Tribune, Edited in Paris, May 27, 1998 at 9.

10. Ibid., at 5.

11. J. Méndez, "The Right to Truth," in Joyner \& Bassiouni eds., supra note 5, 255 at 263.
12. See Amnesty International, Disappearances and Political Killings: Human Rights Crisis of the 1990's-A Manual for Action, (Amsterdam: Amnesty International, 1994) at 167-68. Amnesty International's recommendations were specifically oriented towards redress for victims of forced disappearances, but can be applied to victims of other state-supported crimes.

13. See, for example, Art. 9 and Art.14 of the International Covenant on Civil and Political Rights, 19 December 1966, 999 U.N.T.S. 171.

14. See J. Dyke and G. Berkley, "Redressing Human Rights Abuses," (1992) 20:2 Denver Journal of International Law and Policy 243 at $244-45$. They identify several sources of international law that compel states to prosecute human rights abuses, including treaties (e.g., Convention on the Prevention and Punishment of Genocide, December 9, 1946, 7 U.N.T.S. 227; Convention against Torture and Other Cruel, Inhuman or Degrading Treatment or Punishment, February 4, 1985, 23 I.L.M. 1027 (1984); etc.); customary law, as exemplified by the Nuremberg and Tokyo trials; and jurisprudence, such as theruling in the Velazquez Rodriguez Case 28 I.L.M. 291 (1989), where theInter-American Courton Human Rights stated that each state party has a "legal duty to take reasonable steps to prevent human rights violations and to use the means at its disposal to carry out a serious investigation of violations committed within its jurisdiction, to identify those responsible, to impose the appropriate punishment and to ensure the victim adequate compensation."

15. D. Cassel, "Lessons From the Americas: Guidelines For International Response to Amnesties For Atrocities," (1996) 59:4 Law and Contemporary Problems 197 at 200.

16. Ibid., Justice Richard Goldstone quoted at 222.

17. A. Boraine, "Reining in Impunity for International Crimes and Serious Violations of Fundamental Human Rights," in Joyner \& Bassiouni, eds., supra note 5, 221 at 22223.

18. H.S.Greve, "DoNot Interfere ...' Recording the Facts and the Truth," in Joyner \& Bassiouni, eds., supra note 5, 245 at 252.

19. C. Bassiouni, Accountability, supra note6, at 56.

20. C. Bassiouni, International Crimes, supra note 5 , at 137.

21. Canada has successfully prosecuted a number of Nazi war criminals residing in Canada: see I. Cotler, "National Prosecutions, International Lessons: Bringing Nazi War Criminals in Canada to Justice," in
Bassiouni \& Joyner, eds., supra note 5 at 161. In Belgium, the Law of 16 June 1993 explicitly affirms the principle of universality for war crimes: see $M$. Swartenbroekx, "Moyens et limites du droit belge," in A. Destexhe \& M. Foret, eds., De Nuremberg a La Haye et Arusha, (Brussels: Bruylant, 1997) at 122.

22. SeeG.Wakjira, "National Prosecution: The Ethiopian Experience," in Bassiouni and Joyner, eds., supra note 5, 189 at 189.

23. For a detailed treatment of the domestic trials of military leaders of the "Dirty War" in Argentina, see J. Malamud-Gotti, Game Without End: State Terror and the Politics of Justice (Norman, OK and London: University of Oklahoma Press, 1996).

24. SeeS. Landsman, "Alternative Responses To Serious Human Rights Abuses: Of Prosecution and Truth Commissions" (1996) 59:4 Law and Contemporary Problems, 81 at 85 .

25. See C. Bassiouni, "From Versailles to Rwanda in Seventy-Five Years: The Need to Establish a Permanent International Criminal Court" (1997) 10 Harvard Human Rights Journal 11 at 29.

26. B. Ferencz, quoted in International Campaign For the Establishment of the International Criminal Court in 1998 (Rome: XPRESS-ROME, 1997) at 35-36.

27. See, for example, A. Wieviorka, "Les Procès de Nuremberg et d'Eichmann, en perspective," in Destexhe \& Foret, supra note 21, 23 at 25.

28. See Kritz, supra note 8 at 130.

29. See C. Bassiouni, supra note 25 at 45.

30. Ibid., at 39-45. a

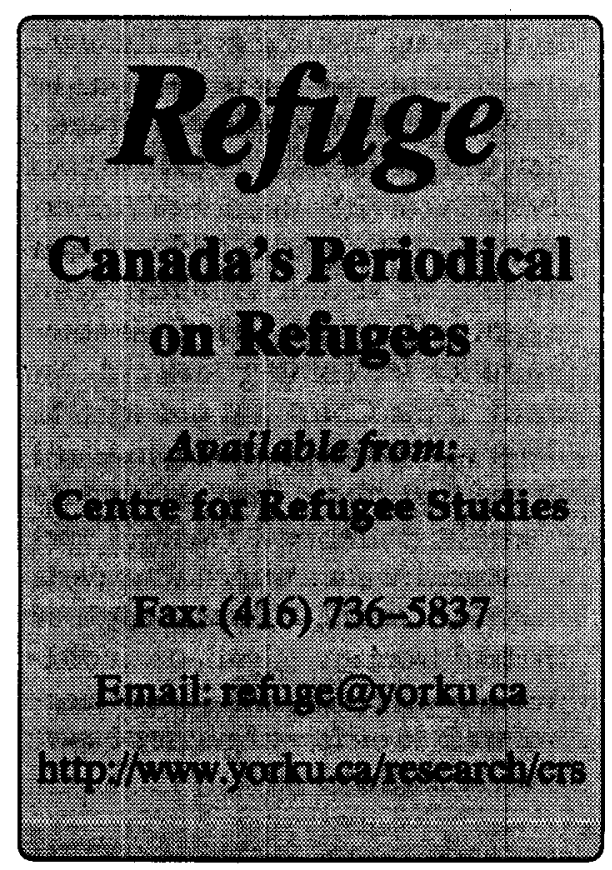

